\title{
UJI AKTIVITAS ANTIHIPERGLIKEMIA EKSTRAK ETANOL 70\% Echinometra mathaei PADA TIKUS PUTIH JANTAN GALUR WISTAR YANG DIINDUKSI ALOKSAN
}

\author{
(Hiperglycemia Activity of 70\% Ethanol Extract of Echinometra Mathaei in Male Wistar \\ Rat Induced by Alloxan)
}

\author{
Angelica Kresnamurti ${ }^{1}$, Suresti Suresti ${ }^{1}$, Iwan Sahrial Hamid ${ }^{2}$ \\ ${ }^{1}$ Prodi Farmasi, Fakultas Kedokteran, Universitas Hang Tuah, Surabaya, Indonesia \\ ${ }^{2}$ Bagian Farmakologi, Fakultas kedokteran Hewan, Universitas Airlangga, Surabaya, Indonesia
}

Email: angelica.kresnamurti@hangtuah.ac.id

\begin{abstract}
Sea urchin (Echinometra mathaei) contains a compound of Echinochrome A, which is a polyhydroxy naphthoquinone that is known to be potential antioxidant. The antioxidant effect correlated with the antidiabetic activity that associated with oxidative stress conditions. The aim of this study was to determine the effect of $70 \%$ Ethanol Extract of sea urchin (Echinometra mathaei) on blood glucose levels in alloxan induced rats. This research was an experimental study using 30 male white rats, divided into 6 groups, i.e the negative control group (normal rat were only given $\mathrm{CMC} \mathrm{Na} \mathrm{0,5 \% ),} \mathrm{Positive} \mathrm{control} \mathrm{group} \mathrm{(hyperglycemic} \mathrm{rats} \mathrm{were} \mathrm{only} \mathrm{treated} \mathrm{with} \mathrm{CMC} \mathrm{Na}$ $0,5 \%$ ), metformin group as a refference standard group (hyperglycemic rats that treated with metformin) and the treatment group (hyperglycemic rats were treated with ethanol extract $70 \%$ of Echinometra mathaei dose of $100 \mathrm{mg} / \mathrm{kgBW}, 200 \mathrm{mg} / \mathrm{kgBW}$ and 400 $\mathrm{mg} / \mathrm{kgBW}$ ). Alloxan monohidrat $120 \mathrm{mg} / \mathrm{KgBW}$ was used as diabetogen agent. The parameters examined in this study were blood glucose levels of rats after 7 days of treatment. The observational data were analyzed using the One Way ANOVA $(\mathrm{P}<0.05)$ and continued with LSD. The results of this study showed that all doses of ethanol extract significantly reduced blood glucose levels in rats compared to the control group. The most effective dose in reducing blood glucose levels and compared to metformin was $400 \mathrm{mg} / \mathrm{kgBW}$.
\end{abstract}

Key word: alloxan induced, Echinometra mathaei, ethanol 70\%, hiperglycemia, marine product.

\section{PENDAHULUAN}

Hiperglikemia adalah kondisi medik dimana terjadi peningkatan kadar glukosa di dalam darah yang melebihi batas normal. Hiperglikemia persisten merupakan tanda khas dari penyakit diabetes mellitus. Berdasarkan Internasional Diabetes Federation sebanyak 183 juta orang tidak menyadari bahwa mereka mengidap penyakit diabetes mellitus (IDF, 2011). Berdasarkan NCD World Health Organization (WHO) tahun 2010, Diabetes Mellitus menduduki peringkat ke-6 sebagai penyebab kematian. Akibat dari diabetes, sekitar 1,3 juta orang meninggal dan sebelum usia 70 tahun sebanyak 4\% yang meninggal. Pada tahun 2030 diperkirakan 21,3 juta jiwa yang mengalami diabetes mellitus di Indonesia (Depkes RI, 2013).

Meningkatnya prevalensi penyakit DM dari tahun ke tahun memerlukan perhatian yang sangat besar dalam pengobatannya. Selama ini pengobatan yang telah dilakukan untuk penderita DM adalah injeksi insulin, Oral Anti Diabetik (OAD) seperti golongan sulfonilurea, glinid, biguanida, penghambatan $\alpha$-glukosidase, thiazolidinedion dan
DPP IV Inhibitor. Kemungkinan obat-obat sintetik tersebut harganya relatif lebih mahal dan dapat menyebabkan berbagai efek samping. Efek samping akut dari obat antidiabetes oral golongan biguanid adalah rasa tidak nyaman pada sistem pencernaan seperti mual dan diare (Godman \& Gilman, 2007).

Salah satu alternatif untuk dalam menunjang terapi diabetes adalah menggunakan obat yang berasal dari bahan alam (obat herbal atau produk biota laut). Penelitian obat bahan alam yang digunakan untuk mengatasi diabetes mellitus untuk bahan obat herbal sudah banyak dilakukan, sedangkan penelitian produk biota laut sangat terbatas padahal banyak potensi di dalamnya.

Indonesia merupakan negara yang kaya akan sumber daya alam laut. Salah satunya adalah bulu babi yang merupakan jenis biota laut yang berasal dari filum Echinodermata. Bagian dari bulu babi yang sering digunakan adalah cangkang dan gonad atau telurnya, sedangkan durinya dilaporkan beracun (Dahl, 2010). Gonad pada bulu babi mengandung asam lemak omega-3 sebagai antikolesterol dan asam 
amino sebagai pemacu pertumbuhan dan kesehatan pada manusia (Hardinoto et al, 2016).

Bulu babi diketahui memiliki aktivitas anti inflamasi, antioksidan, dan antikanker. Aktivitas antioksidan polihidroksi naftoquinon (NAPQI) yang diisolasi dari Anthocidaris Crassispina, salah satu jenis dari Bulu Babi, menunjukkan aktivitas antiradikal yang kuat terhadap DPPH, anion superoksida radikal, dan hidrogen peroksida (Kuwahara et al., 2009; Zhou et al., 2011].

\section{II.TINJAUAN PUSTAKA}

Bulu babi termasuk dalam kelompok hewan invertebrata laut, kelas echinodermata yang termasuk dalam kelompok bintang laut, bintang laut rapuh, dan teripang. Mereka memiliki tubuh orbicular yang dilapisi dengan cangkang yang ketat dan ditutupi dengan banyak duri tajam (Amarowicz, 2017). Bulu babi merupakan salah satu komoditas perikanan yang layak untuk dikembangkan. Bulu babi memiliki nilai ekonomis, bagian tubuh yang dikonsumsi adalah gonad atau telurnya. Organisme ini dapat digunakan sebagai sumber makanan bergizi. Asam lemak omega-3 pada gonad bulu babi berkhasiat untuk menurunkan kadar kolesterol dalam tubuh (Hadinoto et al., 2016).

Gonad pada bulu babi juga mengandung Echinochrome A yang merupakan suatu polyhydroxy naphthoquinone yang diketahui memiliki efektivitas antioksidan (Kuwahara et al, 2009). Cangkang bulu babi mengandung polihidroksi dan apelasterosida $A$ dan $B$ (Angka \& Suhartono, 2000). Cangkang bulu babi dapat digunakan sebagai antitumor, antikanker dan antimikroba (Silaban et al, 2013).

Penelitian yang dilakukan oleh Tanjung (2017), tentang analisis bulu babi (Diadema savignyi) sebagai komponen bioaktif dan antioksidan secara in vitro. Antioksidan adalah senyawa atau komponen kimia yang mampu menghambat atau memperlambat kerusakan akibat proses oksidasi dalam kadar atau jumlah tertentu (Kesuma dan Rina, 2015). Radikal bebas memiliki sifat reaktif sehingga menimbulkan kerusakan pada komponen sel seperti DNA, protein, lipid dan karbohidrat. Kerusakan tersebut dapat menimbulkan berbagai kelainan biologis seperti kanker, arterosklerosis, diabetes dan penyakit degeneratif lainnya (Soeksmanto et al., 2007). Pemberian antioksidan dan komponen senyawa polifenol dapat menangkap radikal bebas, mengurangi stres oksidatif, menurunkan ekspresi TNF- $\alpha$. Senyawa fitokimia ternyata mampu memanipulasi dengan berbagai mekanisme sehingga dapat mengurangi komplikasi diabetes melalui pengurangan stres oksidatif, ROS dan TNF- $\alpha$ (Widowati, 2008).
Berdasarkan hal tersebut, maka perlu dilakukan penelitian mengenai aktivitas antihiperglikemia bulu babi (Echinometra mathaei) dengan menggunakan tikus putih jantan yang telah diinduksi dengan aloksan sehingga mengalami hiperglikemia agar dapat diketahui kadar glukosa darah tikus sebelum dan sesudah perlakuan.

\section{III.METODE PENELITIAN}

Penelitian ini merupakan jenis penelitian true experimental laboratories, yang bertujuan untuk mengetahui pengaruh pemberian ekstrak etanol $70 \%$ bulu babi terhadap penurunan glukosa darah tikus diabetes yang diinduksi aloksan.

\section{Alat dan Bahan}

Alat yang digunakan dalam penelitian ini adalah timbangan analitik, timbangan hewan uji, restrainer tikus, kandang tikus, alat-alat gelas, sarung tangan, tempat air minum, pakan hewan, masker, alumunium foil, sendok tanduk, kertas saring, corong buchner, rotavapor, jarum suntik, pisau bedah, glukometer easy touch, blood glucose stick test, kapas, dan tissue.

Bahan yang digunakan pada penelitian ini antara lain bahan uji ekstrak etanol $70 \%$ bulu babi, bahan kimia Aloksan Monohidrat (Sigma-Aldrich, USA), metformin $\mathrm{HCl}$, aquadest.

\section{Prosedur Penelitian \\ 3.1 Koleksi dan Determinasi Echinometra mathaei}

Echinometra mathaei dikoleksi dari Pulau Weh, Sabang, Nanggroe Aceh Darussalam pada Bulan Oktober 2018. Sampel yang diperoleh berupa Bulu babi dengan warna hitam keunguan pada kedalaman 5-10 meter di bawah permukaan laut.

Determinasi dilakukan dengan cara mencocokkan bagian-bagian dari bulu babi Echinometra mathaei sesuai dengan ciri-ciri morfologinya untuk menetapkan kebenaran yang berkaitan dengan bulu babi Echinometra mathaei. Determinasi dilakukan dengan mengirimkan sampel uji ke Laboratorium Biologi Universitas Airlangga Surabaya.

\subsection{Preparasi Sampel Bulu Babi Echinometra mathaei}

Sampel bulu babi Echinometra mathaei dicuci bersih dan dibilas dengan air tawar yang mengalir untuk membersihkan kotoran-kotoran dan garamgaram yang menempel. Kemudian sampel ditiriskan dan dipisahkan dari durinya, sedangkan bagian cangkang dan gonadnya dijemur hingga kering. Sampel yang sudah kering dihaluskan dengan mesin 
penggiling untuk mendapatkan serbuk halus Echinometra mathaei.

\subsection{Ekstraksi Sampel Bulu Babi Echinometra mathei}

Serbuk Echinometra mathaei diekstraksi dengan menggunakan metode ekstraksi maserasi. Simplisia serbuk dimasukkan ke dalam toples kaca dengan pelarut etanol $70 \%$. Maserasi dilakukan selama 3 hari dengan seringkali diaduk, perbandingan pelarut yang digunakan diantaranya 1:10 (b/v). Setelah 24 jam rendaman simplisia disaring dengan menggunakan corong buchner dan kertas saring. Ampasnya dipisahkan dan hasil dari penyaringan disebut maserat I. Ampas kemudian di maserasi kembali dengan cara di atas sebanyak dua kali sehingga diperoleh maserat II dan maserat III.

Semua maserat dikumpulkan lalu dipekatkan dengan menggunakan rotary evaporator sampai diperoleh ekstrak kental, kemudian dimasukkan ke dalam desikator sampai terbentuk ekstrak kering. Ekstrak kering yang didapat ditimbang

\subsection{Pengujian Aktivitas Antihiperglikemia}

Sebelum penelitian tikus diaklimatisasi selama 7 hari di kandang, diberikan makan dan minum ad libitum, pengaturan suhu kandang $28 \pm 2^{\circ} \mathrm{C}$, tiap tikus dimasukkan pada kandang terpisah (single cage). Setelah tikus diaklimatisasi selama 7 hari di kandang, tikus dikelompokkan secara acak menjadi 6 kelompok dengan masing-masing terdiri dari 5 tikus jantan, yaitu kelompok kontrol negatif (tikus normal diberikan CMC Na 0,5\%), kelompok kontrol positif (tikus diabetes yang diberikan CMC $\mathrm{Na}$ 0,5\%), kelompok pembanding (tikus diabetes yang diberikan Metformin $\mathrm{HCl}$ ), dan kelompok ekstrak (tikus diabetes yang diberikan ekstrak Echinometra mathaei dosis 100, 200, dan $400 \mathrm{mg} / \mathrm{KgBB}$ ).

Semua tikus percobaan dicatat KGD normal sebelum perlakuan. 25 ekor tikus diinduksi dengan aloksan monohidrat secara intramuskular dengan dosis tunggal $120 \mathrm{mg} / \mathrm{kgBB}$. Perjalanan terjadinya hiperglikemia tikus diamati setiap hari selama satu minggu. Satu minggu setelah penyuntikan aloksan, kadar glukosa darah tikus dicatat sebagai $\mathrm{t}=0$. Tikus yang mengalami hiperglikemia dengan KGD $\geq 200$ $\mathrm{mg} / \mathrm{dl}$ diberikan perlakuan sesuai kelompok masingmasing. Data KGD tikus dicatat setiap hari selama 7 hari. Penurunan KGD dihitung sebagai prosentase dibandingkan dengan KGD normal dengan rumus sebagai berikut :

\% Perlakuan KDG

$=\frac{\text { KDG normal }-K D G \text { setelah KDG normal }}{\text { perlakuan }} \times 100 \%$
\% Efektivitas penurunan KGD dihitung untuk mengetahui efektivitas ekstrak dalam setiap dosis untuk menurunkan KGD dibandingkan dengan metformin

$\%$ Efektivitas penurunan

$=\frac{\% \text { penurunan obat } \mathrm{A}}{\% \text { penurunan metformin }} \times 100 \%$

Penelitian ini telah mendapatkan surat kelaikan etik penelitian praklinis dari Komisi Etik Penelitian Kesehatan Fakultas Kedokteran Universitas Hang Tuah Surabaya dengan nomor : I/064/UHT.KEPK.03/I/2020.

\section{Analisis Data}

Data KGD yang telah didapatkan diolah secara statistik dengan menggunakan software SPSS versi 22. Analisis data dilakukan adalah dengan Anava satu arah (oneway Anova) pada $\mathrm{P}<0.05$, dan dilanjutkan dengan uji LSD (Least Significant Difference) untuk mengetahui kelompok mana yang menunjukkan perbedaan bermakna.

\section{HASIL DAN PEMBAHASAN}

Pada penelitian ini digunakan aloksan monohidrat yang disuntikkan secara i.m sebagai penginduksi hiperglikemia. Aloksan merupakan agen diabetogenik yang cukup memadai untuk digunakan sebagai penginduksi diabetes pada hewan percobaan dengan cepat. Pemberian aloksan mampu meningkatkan KGD tikus pada pemberian dosis tunggal. Pada penelitian ini tampak bahwa dari 25 ekor tikus yang diinduksi aloksan, dapat meningkatkan KGD tikus rata-rata sebesar 343,30 $\mathrm{mg} / \mathrm{dL}$ pada hari ke-3 setelah pemberian aloksan (tabel 1).

Tabel 1. Peningkatan KGD setelah induksi aloksan

\begin{tabular}{cc}
\hline Rata-rata & Rata-rata KGD setelah \\
KGD normal & induksi aloksan \\
$(\mathrm{mg} / \mathrm{dL})$ & $(\mathrm{mg} / \mathrm{dL})$
\end{tabular}

$113,05 \pm 13,91 \quad 456,35 \pm 98,37$

Menurut Kroon dan Williams (2013) metformin merupakan terapi antidiabetes golongan biguanid yang meningkatkan kepekaan tubuh terhadap insulin yang diproduksi oleh pankreas, tidak merangsang peningkatan insulin sehingga pemakaian tunggal tidak berakibat 
E-ISSN : 2715-0518 P-ISSN : 2715-3053 hal 29-34

hipoglikemia. Metformin tidak memiliki efek langsung pada sel $\beta$-pankreas, meskipun kadar insulin menurun. Diketahui bahwa efek utama dari obat ini adalah menurunkan produksi glukosa hepatik melalui aktivitas enzim AMPactivated protein kinase dan meningkatkan stimulasi ambilan glukosa oleh otot skelet dan jaringan lemak sesuai penelitian yang dilaporkan oleh Katzung (2011). Pada kelompok pembanding mengalami penurunan kadar glukosa darah sebesar $154,75 \mathrm{mg} / \mathrm{dL}$.

Pada penelitian ini terlihat bahwa pemberian ekstrak Echinometra mathaei pada semua dosis memberikan efek penurunan KGD dan efeknya meningkat dengan peningkatan dosis ekstrak (tabel 2).

Tabel 2. Kadar Glukosa Darah Tikus

\begin{tabular}{|c|c|c|c|}
\hline \multirow[t]{2}{*}{ Kelompok } & \multirow{2}{*}{$\begin{array}{l}\text { KGD normal } \\
\text { Sebelum } \\
\text { perlakuan }\end{array}$} & \multicolumn{2}{|c|}{$\begin{array}{l}\text { Rata-rata Kadar Glukosa } \\
\text { darah Tikus }\end{array}$} \\
\hline & & Hari ke-0 & Hari ke-8 \\
\hline Kontrol negatif & $105,50 \pm 28,64$ & $\begin{array}{c}117,25 \pm \\
16,32\end{array}$ & $\begin{array}{c}114,50 \pm \\
10,15^{\mathrm{b}}\end{array}$ \\
\hline Kontrol positif & $118,50 \pm 10,41$ & $\begin{array}{c}600,00 \pm \\
0,00\end{array}$ & $\begin{array}{c}280,25 \pm \\
45,02^{\mathrm{a}}\end{array}$ \\
\hline Metformin & $109,75 \pm 3,78$ & $\begin{array}{c}345,25 \pm \\
61,66\end{array}$ & $\begin{array}{c}190,50 \pm \\
38,00^{\mathrm{ab}}\end{array}$ \\
\hline $\begin{array}{l}\mathrm{EM} \text { dosis } 100 \\
\mathrm{mg} / \mathrm{KgBB}\end{array}$ & $111,00 \pm 24,94$ & $\begin{array}{c}456,75 \pm \\
113,04\end{array}$ & $\begin{array}{c}172,25 \pm \\
68,81^{\mathrm{a}}\end{array}$ \\
\hline $\begin{array}{l}\mathrm{EM} \text { dosis } 200 \\
\mathrm{mg} / \mathrm{KgBB}\end{array}$ & $127,25 \pm 7,72$ & $\begin{array}{c}401,25 \pm \\
190,97\end{array}$ & $\begin{array}{c}199,00 \pm \\
85,41^{\text {ab }}\end{array}$ \\
\hline $\begin{array}{l}\mathrm{EM} \text { dosis } 400 \\
\mathrm{mg} / \mathrm{KgBB}\end{array}$ & $98,75 \pm 22,69$ & $\begin{array}{c}478,50 \pm \\
126,18\end{array}$ & $\begin{array}{c}158,50 \pm \\
85,78^{\mathrm{a}}\end{array}$ \\
\hline
\end{tabular}

Ket : notasi yang berbeda menunjukkan perbedaan bermakna pada $\mathrm{P}<0,05$

Diabetes mellitus merupakan penyakit dengan keadaan yang berhubungan stres oksidatif yang menyebabkan kerusakan fungsi sel $\beta$ pankreas dan resistensi insulin. Perubahan status oksidatif pada diabetes mellitus ditandai dengan perubahan aktivitas antioksidan endogen serta meningkatnya kerusakan biomolekul secara oksidatif. Antioksidan eksogen diperlukan untuk menghambat kerusakan oksidatif di dalam tubuh (Setiawan dan Suhartono, 2005). Penelitian ini sejalan dengan peneitian ayng dilaukan oleh Widowati (2008) bahwa mekanisme kerja antioksidan dalam menurunkan kadar glukosa darah adalah karena antioksidan memiliki kemampuan sebagai astringen yaitu dapat mempresipitasikan protein selaput lendir usus sehingga menghambat asupan glukosa.

Mekanisme kerja antioksidan tersebut akan menurunkan laju peningkatan glukosa darah. Antioksidan akan mempercepat keluarnya glukosa dari sirkulasi darah dengan mempercepat filtrasi dan ekskresi ginjal sehingga produksi urin meningkat. Peningkatan produksi urin menyebabkan laju ekskresi glukosa melalui ginjal yang menyebabkan kadar glukosa dalam darah menurun. Antioksidan akan mempercepat keluarnya glukosa melalui peningkatan masukan kedalam deposit lemak. Proses ini akan melibatkan pankreas untuk memproduksi insulin.

Prosentase penurunan ekstrak dihitung dengan membandingkan keadaan saat KGD tikus normal dan setelah diberikan ekstrak. Tampak bahwa peningkatan dosis ekstrak tidak menunjukkan peningkatan efek penurunan pada dosis 100 $\mathrm{mg} / \mathrm{KgBB}$ dan $200 \mathrm{mg} / \mathrm{KgBB}$ begitu juga dengan hasil perhitungan prosentase efektivitas ekstrak (tabel 3.).

Efektivitas Echinometra mathaei sebagai antidiabetes pada penelitian ini ditunjukkan dari kerjanya menurunkan KGD tikus putih dibandingkan dengan metformin.

Pada data tampak bahwa pemberian dosis ekstrak $400 \mathrm{mg} / \mathrm{KgBB}$ menunjukkan penurunan KGD dan efektivitas paling tinggi (tabel 3.)

Tabel 3. Prosentase Penurunan KGD dan Efektivitas Penurunan KGD Dibandingkan Metformin

\begin{tabular}{lcc}
\hline Kelompok & $\begin{array}{c}\text { \% Penurunan } \\
\text { KGD }\end{array}$ & $\begin{array}{c}\% \text { Efektivitas } \\
\text { Penurunan }\end{array}$ \\
& & \\
\hline Metformin & $44,82 \%$ & $100 \%$ \\
EM dosis 100 mg/KgBB & $62,29 \%$ & $138,98 \%$ \\
EM dosis 200 mg/KgBB & $50,41 \%$ & $112,47 \%$ \\
EM dosis 400 mg/KgBB & $66,87 \%$ & $149,20 \%$
\end{tabular}

Senyawa yang diduga sangat berperan dalam aktivitas antidiabetes pada bulu babi (Echinometra mathaei) adalah Echinochrome A yang merupakan suatu polyhydroxy naphthoquinone (NAPQI) yang diketahui memiliki efektivitas antioksidan yang tinggi (soelemani et al , 2016). Antioksidan adalah suatu zat yang dapat mencegah serta memperlambat proses oksidasi. Antioksidan berfungsi untuk memperbaiki sel tubuh yang mengalami kerusakan karena radikal bebas. Radikal bebas yang tidak stabil, memiliki elektron yang tidak berpasangan dan mencari pasangan elektron dari senyawa lain. Molekul-molekul antioksidan akan berikatan dengan radikal bebas sehingga dapat mengurangi bahaya radikal bebas yang berpotensi merusak DNA. Hasil penelitian ini sesuai dengan pemaparan Setiawan dan Suhartono (2005) bahwa ketika radikal bebas telah berikatan dengan antioksidan, maka radikal bebas tersebut tidak bisa lagi berikatan dengan dengan sel 
lainnya, sehingga resiko radikal bebas merusak sel lainnya pun hilang atau berkurang

\section{V.PENUTUP}

Berdasarkan penelitian yang telah dilakukan, maka dapat diambil kesimpulan bahwa:

1. Pemberian ekstrak etanol $70 \%$ Echinometra mathaei dapat menurunkan kadar glukosa darah pada tikus yang telah diinduksi aloksan, sehingga mempunyai potensi yang kuat sebagai antidiabetes.

2. Penurunan KGD paling tinggi ditunjukkan pada pemberian dosis 400 $\mathrm{mg} / \mathrm{KgBB}$.

3. Efektivitas Echinometra mathaei sebagai antihiperglikemia lebih tinggi daripada metformin, ditunjukkan pada semua dosis.

\section{UCAPAN TERIMAKASIH}

Penelitian ini mendapatkan bantuan berupa dosen dana penelitian berdasarkan penelitian internal Universitas Hang Tuah Surabaya

\section{DAFTAR PUSTAKA}

1. Amarowicz R, Synowiecki J, Shahidi F. . 2012. Chemical composition of shells from red (Strongylocentrotus franciscanus) and green (Strongylocentrotus droebachiensis) sea urchin. Food Chem. Vol 133 no 3. Hal 822-6.

2. Angka, S. L., \& Suhartono, T. S. (2000). Bioteknologi Hasil Laut. Pusat Kajian Sumber Daya Pesisir dan Lautan. Institut Pertanian Bogor.

3. Dahl, W.J., Jebson, P., \& Louis, D.S. (2010). Sea Urchin Injuries To The Hand: A Case Report And Review Of The Literatur. The Lowa Orthopaedic Journal 30, 153-156. PMID: 21045988

4. Depkes RI (Departemen Kesehatan Republik Indonesia). 2013. Diabetes Mellitus Penyebab Kematian Nomor 6 di Dunia. Jakarta: Departeman Kesehatan,

5. Goodman dan Gilman. 2007. Dasar Farmakologi Terapi, Edisi X. Jakarta: Buku Kedokteran EGC.

6. Hardinoto, S., Sukaryono, D., Siahay, Y. 2016. Nutrition Content of Sea Urchins (Diadema setosum) and the Potential of Its Shell as an Antibacterial. Balai Riset dan Standarisasi Industri Ambon. Universitas Pattimura Program Studi Ilmu Kelautan.
7. International Diabetes Federation. 2015. IDF Diabetes Atlas 7th Edition. Brussels: International Diabetes Federation.

8. Istiqomah. 2013. Perbandingan metode ekstraksi maserasi dan sokletasi terhadap kadar piperin buah cabe jawa (Piperis retrofracti fructus. Skripsi. Jakarta: Fakultas Kedokteran dan Ilmu Kesehatan, Universitas Islam Negeri Syarif Hidayatullah.

9. Katzung, B.G. 2011. Farmakologi Dasar dan Klinik Edisi 10. Jakarta: Penerbit Buku Kedokteran EGC.

10. Kesuma .S., dan Rina .Y. 2015. Antioksidan alami dan sintetik.cetakan 1. Padang: Andalas university press.

11. Kroon, L.A. dan Williams, C., 2013. Diabetes Mellitus, dalam: Koda-Kimble and Young's Applied Theurapeutics; the Clinical Use of Drugs. Lippincott Williams \& Wolters Kluwers, hal. 1223-1300.

12. Kuwahara, R., Yuki, T., Murata, H., Tanaka, R., Hama, Y. 2009. Antioxidant Property Of Polyhydxyled Naphthoquinone Pigments From Shells of Purple Sea Urchin Anthocidaris crassispina. LWT Food Sci. Technol, 42, 1296-1300. DOI : 10.1016/j.lwt.2009.02.020

13. Lenzen, S., 2008. The Mechanism of Alloxan and Streptozotocin Induced Diabetes. Diabetologia 51. p. 216-226. http://dx.doi.org/10.1007/s00125-0070886-7

14. Silaban, Bernita Br dan Endang Sunarwati Srimariana. 2013. Kandungan Nutrisi Dan Pemanfaatan Gonad Bulu Babi (Echinothrixs calamaris) Dalam Pembuatan Kue Bluder. JPHPI. Vol 16 No 2 DOI: https://doi.org/10.17844/jphpi.v16i2. 8045

15. Soleimani, Soolmaz et al. 2016. Identification And Antioxidant Of Polyhydroxylated Naphthoquinone Pigments From Sea Urchin Pigments Of Echinometra Mathaei. Medicinal Chemistry Research. DOI: $10.1007 / \mathrm{s} 00044-016-1586-\mathrm{y}$

16. Soeksmanto, A., Y. Hapsari, P. Simanjuntak. 2007. Kandungan antioksidan pada beberapa bagian tanaman mahkota dewa, Phaleria macrocarpa (Scheff) Boerl. (Thymelaceae). Biodiversitas. Vol 8 no 2. Hal 92-95.

17. Tanjung, Irvan. 2017. Analisis Komponen Bioaktif dan Antioksidan dari Bulu Babi 
E-ISSN : 2715-0518 P-ISSN : 2715-3053 hal 29-34

(Diadema Savignyi) Secara In Vitro Di

Perairan Pulau Bintan Trikora Tiga

Kepulauan Riau. Tanjung Pinang: Fakultas

Ilmu Kelautan Dan Perikanan Universitas Maritim Raja Ali Haji.

18. Triplitt C. L., Reasner C. A., and Isley W.C., 2008. Chapter 77: Diabetes Mellitus. In: (Dipiro J. T., Talbert R. L., Yee G. C., Matzke G. R., Wells B. G., and Posey L. M). Pharmacotherapy: A Patophysiologic Approach 7th Edition. New York: Mc Graw-Hill Companies, Inc., p. 1205-1223.

19. Widowati, W. (2008). Potensi Antioksidan sebagai Antidiabetes. Jurnak Kesehatan Masyarakat. 7(2): Halaman 8.
20. WHO., 2010. The World Health Report 2010.

http://www.who.int./whr/2010/en/index.ht ml Akses 20 Septemer 2019.

21. Zhou DY, Qin L, Zhu BW, Wang XD, Tan H, Yang JF, dkk. 2011. Extraction and antioxidant property of polyhydroxylated naphthoquinone pigments from spines of purple sea urchin Strongylocentrotus nudus. Food Chem. Vol 129 no 4. Hal :1591-7. 